\title{
Optimalisasi Produksi Produk Olahan Berbahan Dasar Salak Di Desa Jatirejo, Kecamatan Diwek, Jombang
}

\author{
Benih Hartanti ${ }^{1}$, Wenda Wahyu Christiyanto ${ }^{2}$, Nuri Purwanto ${ }^{3}$ \\ STIE PGRI Dewantara Jombang
}

Korespondensi: wenda.christiyanto@gmail.com

Diserahkan: 13 Juli 2018, Direvisi: 29 Juli 2018, Diterima: 5 Agustus 2018

\begin{abstract}
Abstrak
Kegiatan pendampingan yang dilakukan tim penulis di Desa Jatirejo, Kecamatan Diwek, Kabupaten Jombang - Jawa Timur dengan sumber dana dari hibah kementrian Riset dan teknologi Pendidikan Tinggi (kemenristekdikti) melalui Program Kerjasama Mitra, bertujuan untuk meningkatkan perekonomian Desa Jatirejo yang terkenal sebagai penghasil buah Salak dengan memberdayakan kelompok ibu-ibu Pemberdayaan Kesejahteraan Keluarga (PKK) sebagai mitra. Kegiatan ini berlangsung selama kurang lebih 3 (tiga) bulan dengan menitikberatkan pada pengolahan buah salak dalam berbagai varian produk yaitu minuman sari salak serta jenang salak, dengan disertai pemberian bantuan alat produksi kepada mitra. Dengan bermodalkan semangat membangun perekonomian desa dan kerja keras serta gotong royong, pada akhirnya produk minuman sari salak dapat dipasarkan dan laku terjual sebanyak 1600 cup ukuran $120 \mathrm{ml}$, dan jenang salak terjual sebanyak $150 \mathrm{Kg}$, dengan sebaran konsumen di wilayah Jawa Timur, Jawa Barat, Jakarta, Bali dan Sulawesi Utara.
\end{abstract}

Kata Kunci : Salak Jatirejo, Sari Salak, Jenang Salak, Program Kerjasama Mitra.

\begin{abstract}
Mentoring activities carried out by the writers team in Jatirejo Village, Diwek District, Jombang Regency - East Java with funding from the Ministry of Research and Higher Education (kemenristekdikti) grant through the Partnership Program, aim to improve the economy of the famous Jatirejo Village as a fruit producer of Salak empowering the women's family empowerment group (PKK) as a partner. This activity lasted for approximately 3 (three) months with emphasis on processing zalacca fruit in various product variants, namely salak juice and jenang salak, accompanied by the provision of production tools to partners. With the spirit of building the village economy and hard work and mutual cooperation, ultimately salak juice beverage products can be marketed and sold as many as 1600 cup sizes of $120 \mathrm{ml}$, and Jenang Salak sold $150 \mathrm{Kg}$, with the distribution of consumers in East Java, West Java, Jakarta, Bali and North Sulawesi.

Keywords: Jatirejo Salak, Sari Salak, Jenang Salak, Partner Cooperation Program.
\end{abstract}

\section{A. PENDAHULUAN}

\section{Latar Belakang}

Kelompok masyarakat Desa adalah salah satu unsur penggerak dalam mewujudkan desa mandiri sesuai dengan program pemerintah sehingga dapat memberikan kontribusi yang cukup signifikan terhadap perkembangan ekonomi daerah. Program pemerintah telah terwujud dalam berbagai macam realisasi kegiatan yang bisa dilaksanakan oleh masing-masing Desa dalam system desentralisasi yang tetap terukur dan dapat dimonitor.

Prioritas utama dari program Kementerian Desa, Pembangunan Daerah Tertinggal, dan Transmigrasi adalah program pengembangan Produk Unggulan Desa (Prudes) dan Produk Unggulan Kawasan Perdesaan (Prukades) (Tempo.co, 2017). 
Pemerintah juga memberikan himbauan agar setiap Desa bisa fokus untuk mengembangkan produk unggulan.

Secara umum, program-program pemerintah telah ditanggapi oleh masing-masing desa melalui beberapa perencanaan kegiatan yang terbagi dalam badan dan struktur yang telah diputuskan oleh masing-masing perangkat desa sesuai kebutuhan masingmasing desa (Rosfadhila, M., Toyamah, N., Sulaksono, B., Devina, S., Sodo, R. J., \& Syukri, M, 2011). Namun, dalam proses riil kegiatan, bahkan saat perencanaan, terdapat berbagai macam tantangan yang menjadi tugas perangkat dan pelaksana desa agar dapat mengoptimalkan kegiatan.

Beberapa Badan yang dibentuk oleh masing-masing Desa dengan tujuan untuk memaksimalkan program desa mandiri antara lain adalah Badan Usaha Milik Desa (BUMDes), Badan Kredit Daerah, Koperasi Wanita dan beberapa bentuk Koperasi lain yang umumnya dibentuk untuk membantu kebutuhan masyarakat desa. Ekspektasi hasil dari pemerintah tentu saja bukan suatu perkara yang mudah diwujudkan oleh perangkat desa sebagai penggagas, pengawal sekaligus pengawas kegiatan ekonomi desa, peran paling penting dari setiap perencanaan dan pelaksanaan adalah masyarakat desa sendiri (Zulfikar, W. ,2017).

Desa Jatirejo, Kecamatan Diwek, Kabupaten Jombang dikenal sebagai Desa penghasil salak di Jombang. Banyaknya penduduk yang memiliki kebun salak secara turun temurun dan rasa khas salak Jatirejo memberikan ruang yang cukup besar dalam mengembangkan potensi desa menjadi desa mandiri. Hasil observasi terakhir menunjukkan bahwa salak sebagai bahan baku telah dikembangkan menjadi varian produk seperti jenang dan minuman sari salak.

Meskipun hasil salak sebagai bahan baku cukup melimpah, namun, untuk memenuhi permintaan pasar yang cukup tinggi atas varian produk salak, khususnya jenang, proses produksi yang kurang terencana dan tidak terukur dari segi efektifitas dan efisiensi menjadi hambatan utama dalam mengembangkan potensi produk. Hal ini tidak hanya dihadapi oleh Desa Jatirejo tapi juga wilayah lain yang merupakan sentra penghasil salak (Prawoto, N. (2012). Kelompok desa Jatirejo, Pondok Salak yang seharusnya dibentuk untuk memprioritaskan kegiatan mereka dalam mengolah hasil salak menjadi tidak produktif di saat permintaan cukup tinggi. Sebagai iconic product dari desa Jatirejo, keterlibatan berbagai pihak pada setiap lapisan perangkat desa, masyarakat dan kelompok desa sangat diperlukan dalam proses pengembangan produk yang lebih produktif sehingga bisa memenuhi permintaan pasar.

\section{Profil Mitra}

Latar belakang yang penulis gunakan acuan mengenai pemilihan mitra adalah kemauan kuat dari Ketua Kelompok dan Kepala Desa dalam mengembangkan produk unggulan Desa Jatirejo agar lebih dapat menjangkau pasar yang lebih luas di Kabupaten Jombang. Selain itu, agar banyaknya sumberdaya kebun salak yang dimiliki oleh penduduk Desa bisa memiliki nilai lebih dan menjadi salah satu sumber keswadayaan penduduk yang utama. Stelah melalui berbagai pertimbangan, maka mitra yang dipilih dalam kegiatan PKM ini adalah Kelompok Pondok Salak.

Kelompok Pondok Salak, Di Desa Jatirejo, terbentuk untuk menggagas produktifitas hasil salak agar lebih bervariasi dan semakin dikenal. Kelompok ini terdiri dari anggota Ibu-ibu PKK dari beberapa dusun Jatirejo yang tergabung menjadi satu. Kegiatan yang telah dilakukan sejak kelompok dibentuk adalah mengolah hasil salak menjadi produk bernilai lebih seperti jenang dan minuman sari salak. Buah salak 
sebagai bahan baku utama dihasilkan dari kebun beberapa anggota kelompok. Secara umum, anggota kelompok yang memiliki kebun salak memanen buah salak untuk selanjutnya dikumpulkan dari beberapa anggota kelompok dan penduduk desa lain yang memiliki kebun salak namun tidak tergabung dalam kelompok. Kegiatan kelompok Pondok Salak dipantau oleh Kepala Desa yang dalam setiap kegiatan rutin seperti pertemuan PKK, Posyandu dan kegiatan lain.

Sesuai dengan tujuan kelompok tersebut dibentuk, yaitu meningkatkan produktifitas hasil salak dan variannya, ruang untuk optimalisasi masih sangat besar. Sesuai tujuan kelompok dibentuk yaitu meningkatkan produktifitas hasil salak, hasil observasi penulis menunjukkan bahwa produktifitas pengolahan hasil salak mengalami penurunan, bahwa untuk beberapa waktu selama penulis mengamati, penduduk secara umum dan anggota kelompok secara khusus bahkan sudah tidak mengolah hasil panen lagi sehingga nilai jual dari buah salak sekedar harga penjualan buah salak yang dari tahun ke tahun tidak mengalami peningkatan sedangkan biaya perawatan kebun salak cukup tinggi. Hasil pengamatan inilah yang menjadi perhatian dan secara khusus menjadi tantangan bagi penulis sebagai akademisi untuk menjawab tantangan atas fenomena yang terjadi dan selanjutnya bisa memberikan kontribusi yang signifikan terhadap peningkatan produktifitas hasil khususnya dan meningkatkan kesejahteraan penduduk secara umum.

Potensi dan peluang dari usaha mitra sangat tinggi dilihat dari bahan baku dan permintaan pasar. Total kebun salak yang ada di desa Jatirejo terbagi dalam kepemilikan masing-masing penduduk. Dari segi geografis dengan tekstur tanah dan iklim di desa Jatirejo sangat memungkinkan untuk menghasilkan buah salak yang khas dan enak. Peluang dari pengembangan hasil salak sangat tinggi dikarenakan rasa salak yang khas dari desa Jatirejo cukup dikenal sejak dahulu dan selalu dijadikan oleh-oleh khas pengunjung kota Jombang. Hasil olah buah salak pun juga sangat diminati oleh masyarakat, dalam satu kali produksi, jenang salak yang menjadi produk olahan utama telah terjual dalam waktu singkat. Namun, sekali lagi, tantangan yang harus terjawab dan dapat diatasi adalah keterlibatan penuh anggota kelompok dalam proses pengolahan hasil salak yang secara konsisten bisa memenuhi permintaan pasar. Pelatihan dan pendampingan yang terencana, terarah, terukur dan berkelanjutan sangat memungkinkan untuk memenuhi ekspektasi peningkatan potensi dan peluang usaha agar lebih efektif dan efisien. Kesadaran masyarakat harus ditingkatkan bahwa pengolahan salak secara professional, bisa meningkatkan perekonomian keluarga (Sumantra, I. K., Yuesti, A., \& Sudiana, A. K. (2015)

Berdasarkan hasil pengamatan penulis, proses produksi pengolahan hasil salak Jatirejo memang masih konvensional karena setiap tahapan produksi masih menggunakan tenaga manusia, mulai memanen buah sampai menjadi hasil olahan produk jenang. Pada dasarnya, kelompok Pondok Salak dan penduduk memiliki pandangan dan gambaran dalam meningkatkan produktifitas hasil olahan, namun dikarenakan tenaga dan waktu yang habis digunakan dalam sekali proses produksi membuat anggota kelompok sedikit enggan untuk melakukan proses produksi secara rutin dan berkala.

Produksi yang kurang maksimal pada dasarnya disebabkan karena manajemen usaha yang kurang optimal. Manajemen usaha ini meliputi perhitungan harga pokok dan harga jual dengan hasil margin yang sangat minim. Margin yang minim inilah yang menyebabkan demotivasi anggota kelompok sebagai pengelola bahkan penduduk lain sebagai pemilik kebun. Dalam jangka panjang, hal tersebut membentuk pandangan 
anggota kelompok yang mengarah pada hasil olahan salak tidak akan memberikan nilai lebih kepada anggota dan desa baik secara ekonomi maupun sosial kultur.

Berdasarkan uraian singkat mengenai proses produksi usaha mitra, hal ini dapat menunjukkan kaitan erat dengan manajemen usaha yang masih jauh dari kata ideal. Pengetahuan kelompok hanya terbatas pada bagaimana mengelola buah salak menjadi satu olahan produk, sedangkan untuk membuat suatu produk lebih dikenal dan usaha menjadi lebih berkembang, pengelola usaha dalam hal ini adalah anggota kelompok harus menggali pengetahuan yang sebanyak-banyaknya mengenai faktor manajemen lain seperti keuangan dan pemasaran yang menjadi fokus utama usaha. Kerjasama yang cukup terintergrasi dengan badan dan atau lembaga Desa lain juga perlu dibangun agar dapat memberikan masukan serta dukungan bagi kelompok usaha agar dapat memberikan arah yang sesuai dengan nilai Desa.

Pada dasarnya, tantangan ini masih sangat memberikan ruang untuk perbaikan. Berdasarkan hasil pengamatan lanjutan penulis, dapat diperoleh informasi bahwa biaya untuk proses pengolahan sangat bisa diminimalisasi dengan penggunaan beberapa alat yang bisa mempercepat sekaligus meningkatkan kuantitas produk. Kepercayaan diri anggota kelompok terhadap harga jual yang bisa diterima juga sangat rendah, sehingga dengan kualitas produk yang bisa dihasilkan, harga jual seharusnya sangat bisa ditingkatkan. Begitu juga dengan pemasaran, saat ini, proses pemasaran hanya melalui orang peroangan dengan dimulai dari anggota kelompok sekaligus pengelola produk, pun demikian, tingkat penjualan sudah sangat tinggi dilihat dari total kuantitas barang yang diproduksi. Dari uraian tersebut dapat disimpulkan bahwa potensi untuk pengembangan produk sangat tinggi dan yang paling dibutuhkan adalah kemauan dari anggota kelompok ataupun Desa secara umum untuk meningkatkan manajemen usaha, khususnya dari proses produksi, keuangan dan pemasaran yang lebih efektif dan efisien.

\section{B. TINJAUAN PUSTAKA \\ 1. Salak Pondoh}

Salak pondoh adalah salah satu kultivar salak yang banyak tumbuh di Indonesia. Salak pondoh memiliki ciri rasa yang manis atau tidak sepet sejak buah masih muda.Salak pondoh (Salacca zalacca Gaertner Voss) termasuk famili palmae, berduri dan bertunas banyak, tumbuh menjadi rumpun yang rapat. Salak pondoh termasuk dalam buah tropis. Salak pondoh memiliki berbagai macam varietas di Indonesia sendiri salak pondoh yang dibudidayakan adalah salak pondoh merah, salak pondoh super, salak pondoh hitam dan salak pondoh kuning. (https://id.wikipedia.org/wiki/Salak_pondoh)

\section{Permasalahan Mitra}

Berdasarkan hasil observasi awal dan wawancara penulis dengan mitra dan perangkat desa, diperoleh informasi mengenai permasalahan yang dihadapi oleh kedua mitra, antara lain sebagai berikut:

1. Aspek sumberdaya manusia yang berkaitan dengan kemampuan manajemen usaha sehingga khususnya kapasitas produksi, pengelolaan biaya dan pemasaran

2. Produk yang dihasilkan belum memiliki ijin BPOM dan Hak Paten, sehingga proses penjualan masih dalam kalangan sendiri dan orang-perorangan sehingga cakupan pasar masih sangat terbatas

3. Diferensiasi produk masih sangat minim yang disebabkan oleh kurangnya pengetahuan mitra terhadap proses produksi dan pengelolaan biaya varian produk 
4. Sumberdaya modal dalam meningkatkan kapasitas produksi sehingga tidak dapat memenuhi permintaan pasar

5. Dukungan dalam bentuk pendampingan dan pelatihan dalam setiap fokus utama pengembangan, khususnya aspek manajemen seperti produksi, akuntansi biaya dan pemasaran yang sangat dibutuhkan mitra

\section{Solusi yang Ditawarkan}

Sesuai penentuan prioritas permasalahan mitra yang telah dijabarkan sebelumnya, sudah selayaknya diikuti oleh usulan solusi yang selanjutnya dapat menyelesaikan setiap permasalahan terkait dan berkontribusi meningkatkan potensi usaha mitra. Beberapa solusi yang bisa digunakan dalam mengatasi tantangan usaha mitra adalah sebagai berikut :

Tabel 1. Permasalaha dan Solusi yang Ditawarkan kepada Mitra

\begin{tabular}{|c|c|}
\hline Prioritas Permasalahan & Solusi \\
\hline $\begin{array}{l}\text { Peningkatan efektifitas dan } \\
\text { efisiensi proses produksi }\end{array}$ & Pembelian Mesin Pengolah Adonan \\
\hline Penambahan varian produk & $\begin{array}{l}\text { Beberapa varian produk yang akan } \\
\text { ditambahkan dari hasil olah buah salak adalah : } \\
\text { Minuman sari salak } \\
\text { 1. Komposisi Bahan : (1) Salak (2) Gula Aren } \\
\text { (3) Natrium Benzoat (4) Asam Sitrat } \\
\text { 2. Packaging : Gelas plastik } 120 \mathrm{ml} \text { dalam } \\
\text { kemasan kardus isi } 32 \text { gelas plastik } \\
\text { 3. Alat tambahan yang diperlukan : cup sealer } \\
\text { dan air sealer untuk kemasan gelas plastik, } \\
\text { agar tertutup dengan baik } \\
\text { Teh Sari Salak } \\
\text { 1. Komposisi Bahan : Kulit Salak } \\
\text { 2. Packaging : teh dalam kantong dalam } \\
\text { kemasan plastik bening isi } 5 \text { kantong teh }\end{array}$ \\
\hline $\begin{array}{l}\text { Penyempurnaan kegiatan } \\
\text { pemasaran yang terkait } \\
\text { dengan packaging, penetrasi } \\
\text { pasar dan branding }\end{array}$ & $\begin{array}{l}\text { 1. Perbaruan packaging untuk setiap produk } \\
\text { utama dan tambahan varian produk dengan } \\
\text { tema dan konten yang sama. } \\
\text { 2. Area penjualan disebarkan ke beberapa area } \\
\text { yang lebih luas melalui bazaar yang } \\
\text { diselenggarakan oleh Kabupaten Jombang, } \\
\text { Dinas Koperasi dan Dinas Perindustrian. } \\
\text { 3. Pemanfaatan event tertentu seperti Hari } \\
\text { Raya Idul Fitri agar setiap penduduk wajib } \\
\text { menyajikan produk di setiap rumah. } \\
\text { 4. Pembuatan Spanduk di Desa Jatirejo untuk } \\
\text { membangun branding produk sebagai citra } \\
\text { Desa Jatirejo }\end{array}$ \\
\hline
\end{tabular}




\begin{tabular}{l|l}
\hline \hline Prioritas Permasalahan & \multicolumn{1}{c}{ Solusi } \\
\hline \hline Manajemen usaha & Akuntansi Biaya : \\
& Dokumentasi pengeluaran dan pemasukan \\
& setiap proses produksi yang lebih \\
& terorganisasi sehingga harga pokok \\
& produksi dan harga pokok penjualan bisa \\
& lebih terukur dan nilai keuntungan yang \\
& dihasilkan bisa ditingkatkan \\
& Laporan Pertanggungjawaban : \\
& Laporan dibuat dan didokumentasikan dan \\
& ditujukan kepada BUMDesa sebagai Mitra \\
& Kedua dan Perangkat Desa sebagai acuan \\
evaluasi kinerja kelompok sekaligus bahan & pertimbangan pengembangan sumberdaya, \\
& baik dari sisi keuangan maupun sumberdaya \\
manusia
\end{tabular}

Sumber : Data diolah, 2018

\section{METODE PELAKSANAAN KEGIATAN}

1. Tahapan Pelaksanaan Solusi untuk Menyelesaikan Permasalahan Mitra

Dalam menyeleseaikan permasalahan mitra, beberapa langkah strategis yang akan dilaksanakan disusun dan dikaitkan dengan prioritas permasalahan. Tahapan pertama berkaitan dengan produk utama hasil olah salak, yaitu jenang salak. Untuk optimalisasi produk, langkah yang harus dilakukan adalah menyusun pembelian mesin pengaduk adonan untuk mengoptimalisasi kuantitas dari hasil olahan salak. Segera setelah mesin diperoleh, penyusunan anggaran harga pokok produksi baru dengan peningkatan jumlah bahan baku dan packaging baru dibuat untuk memberikan acuan yang jelas mengenai harga pokok penjualan yang lebih kompetitif.

Tahapan kedua dikaitkan dengan penambahan varian produk baru seperti, minuman sari salak dan teh. Langkah pertama yang akan dilaksanakan adalah membuat product tester untuk masing-masing jenis varian produk yang selanjutnya akan diujicobakan sebelum diproduksi dengan kuantitas yang lebih besar. Pembelian beberapa jenis mesin untuk mendukung kemasan yang baik juga akan dilaksanakan untuk menghasilkan produk dengan nilai jual tinggi. Selanjutnya, sekali lagi, penyusunan harga pokok produksi selalu disusun untuk mengukur tingkat efektifitas dan efisiensi dengan margin yang diperkirakan.

Tahapan ketiga lebih ditekankan pada pemasaran produk menyeluruh. Langkah yang akan dilaksanakan dikaitkan dengan integrasi kegiatan pemasaran produk utama dan varian produk untuk membangun merek, dimulai dari packaging yang serupa untuk semua produk dengan menekankan "Pondok Salak, Jatirejo, Jombang" sebagai nama merek. Selanjutnya, untuk meningkatkan awareness akan nama produk, produk dikoordinasikan sebagai jamuan utama dalam beberapa event yang diselenggarakan di dalam dan di luar kegiatan desa. Selain itu, distribusi produk juga akan memanfaatkan beberapa acara lain yang diselenggarakan oleh Kabupaten Jombang, seperti Bazar dan Expo. 
Tahapan terakhir akan difokuskan pada sistem pencatatan yang terkoordinasi, tertelusur dan terukur dalam bentuk Laporan Pertanggungjawaban dan Laporan Keuangan sederhana dengan mengikuti Standar Akuntansi Keuangan ETAP yang dapat dijadikan acuan konkret dalam pengambilan keputusan untuk pengembangan produk atau kegiatan selanjutnya.

\section{Metode Pendekatan untuk Menyelesaikan Permasalahan Mitra}

Metode pendekatan yang akan digunakan dalam menyelesaikan permasalahan prioritas yang telah ditentukan yaitu pendampingan intensif pada mitra. Konkret kegiatan pendampingan adalah dengan melaksanakan kegiatan teknis seperti keterlibatan dalam proses produksi varian produk baru, desain kemasan dan label dengan mengangkat nilai merek, mendampingi mengurus perizinan sekaligus pembinaan dalam penyusunan anggaran dan laporan keuangan serta sistem dokumentasi lain yang diperlukan. Beberapa pekerjaan ini sangat membutuhkan keahlian seperti sense of art dalam desain kemasan sebagai aplikasi ilmu pemasaran yang menekankan pada branding.

\section{Partisipasi Mitra dalam Proses Pelaksanaan Program}

Keterlibatan dan partisipasi mitra sebagai pelaku usaha menjadi titik tumpu utama keberhasilan program PKM. Ketentuan atas mekanisme dan metode pelaksanaan yang telah didiskusikan dan disepakati akan menjadi acuan utama dalam setiap tahapan dan proses kegiatan. Partisipasi mitra antara lain adalah kemauan dan komitmen mitra dalam melakukan perubahan demi perkembangan usaha khususnya dan desa Jatirejo umumnya sehingga menuju perbaikan tersebut, mitra akan terlibat sepenuhnya dalam proses pelatihan dan pendampingan. Koordinasi yang baik dalam mengalokasikan partisipasi mitra sekaligus pengusul diharapkan dapat mencapai setiap target luaran serta yang mendorong mitra menjadi pelopor usaha untuk menuju desa mandiri.

\section{Evaluasi Pelaksanaan Program dan Keberlanjutan Program}

Setiap tahapan kegiatan yang mengacu pada prioritas permasalahan mitra akan selalu didokumentasikan sebagai ukuran perbandingan antara anggaran dan realisasi, biaya dan margin serta target luaran dan hasil. Evaluasi akan dilakukan pada setiap solusi kegiatan dan juga akan dilaporkan dalam bentuk laporan tertulis maupun verbal dalam beberapa kali tahapan laporan kepada beberapa pihak yang berkepentingan di lingkungan mitra seperti BUMDesa dan Perangkat Desa. Selanjutnya, keberhasilan atas program akan menjadi acuan dalam program pengembangan berikutnya seperti Program Pengembangan Produk Unggulan Daerah (PPUD) dengan tujuan untuk mengangkat Desa Jatirejo menjadi desa wisata dengan mengangkat hasil olah salak sebagai iconic product dengan nilai kearifan lokal.

\section{HASIL KEGIATAN}

Dari hasil pelaksanaan kegiatan Program Kerjasama Mitra (PKM), Tim pendamping dari STIE PGRI bersama kelompok mitra telah melakukan kegiatankegiatan untuk mencapai target dan luaran yang telah ditentukan, yaitu dengan dimulai diadakannya pelatihan-pelatihan, hingga akhirnya produk olahan salak khas desa Jatirejo dapat dipasarkan kepada masyarakat menjelang Hari Raya Idul Fitri, pada bulan Juni tahun 2018. 
Kegiatan pertama yang dilakukan oleh tim pendamping dari STIE PGRI Dewantara Jombang adalah dengan memberikan pelatihan kepada kelompok mitra tentang motivasi dalam berwirausaha, manajemen usaha, pengelolaan keuangan, serta pendanaan usaha, yang disampaiakan oleh Bapak Bony Hudi, MBA, yang merupakan pelaku bisnis di bidang jasa keuangan berbasis teknologi.

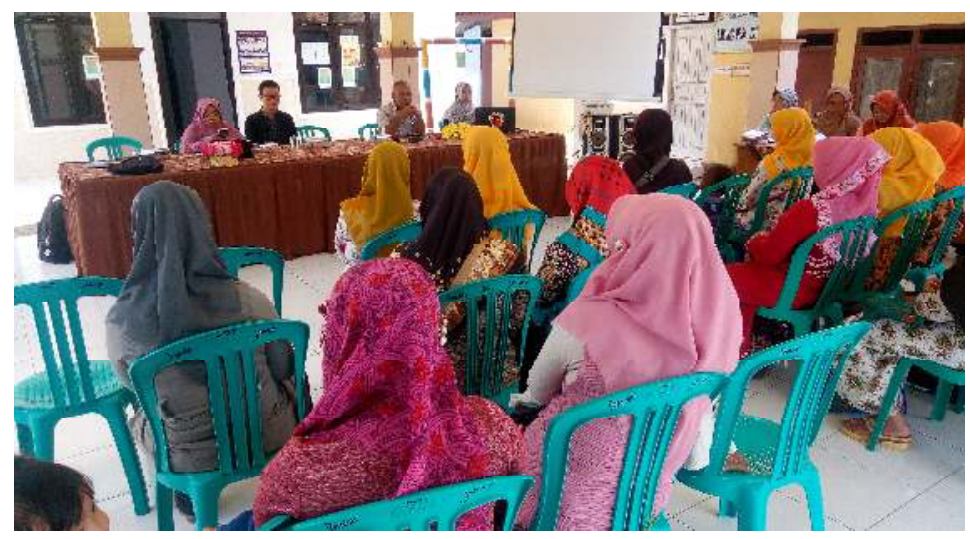

Gambar 1. Pelatihan manajemen usaha

Sumber : Dokumentasi, 2018

Kemudian kegiatan dilanjutkan dengan pembelian alat penunjang produksi, sehingga produksi jenang salak dan sari salak dapat lebih efisien, namun tidak mengurangi kualitas dari produk, yaitu alat pengaduk adonan jenang, alat pasteurisasi, serta alat cup sealer. Kemudian kelompok mitra mulai mendesain logo serta kemasan untuk produk jenang salak dan minuman sari salak. Dikarenakan ada dua produk olahan salak yang diproduksi, maka kelompok mitra dibagi menjadi dua kelompok, di mana kelompok pertama, di bawah koordinasi Ibu Lutfiah Widyastuti, bertugas memproduksi minuman sari salak, sedangkan kelompok kedua, di bawah koordinasi Ibu Mudzakiroh bertugas memproduksi jenang salak.

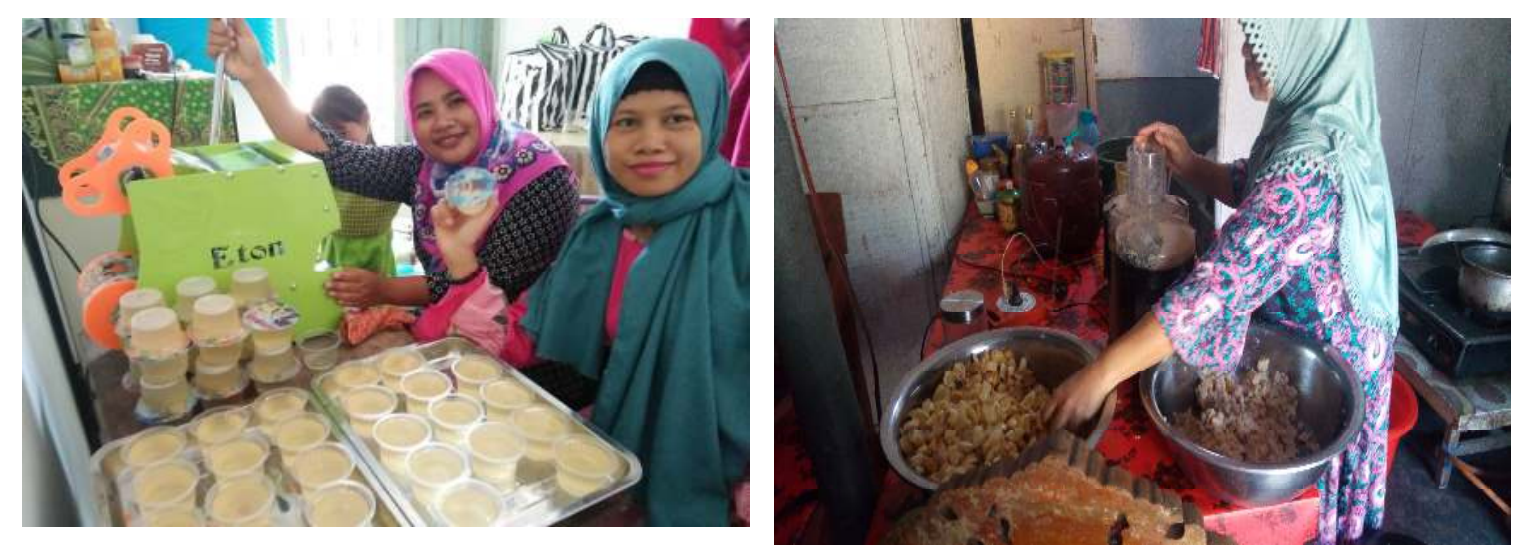

Gambar 2. Proses pembuatan produk olahan salak

Sumber : Dokumentasi, 2018

Produksi awal dilakukan selama bulan Mei hingga Juni Tahun 2018, dengan memanfaatkan momentum menjelang hari Raya Idul Fitri, dengan harapan produk olahan salak Jatirejo dapat terjual sebagai hidangan tamu ketika Hari Raya Indul Fitri. Dukungan terhadap kelompok mitra datang dari pemerintah desa Jatirejo, yang mana 
Bapak Kepala Desa Jatirejo meminta kepada kelompok mitra, untuk menyiapkan produk olahan salak sebagai parcel Idul Fitri, yang akan diberikan kepada seluruh perangkat desa Jatirejo. Selain itu, Bapak Kepala Desa Jatirejo juga mendorong kelompok mitra untuk mengikuti berbagai pameran yang diadakan di Kabupaten Jombang, guna memperkenalkan produk olahan salak desa Jatirejo kepada masyarakat di Kabupaten Jombang.

Ibu Lutfiyah Widyastuti, selaku ketua kelompok mitra, juga telah mengikuti pelatihan PIRT, dan saat ini sedang dalam proses pengajuan PIRT untuk produk minuman sari salak dan jenang salak, sehingga apabila ijin PIRT sudah diperoleh, maka produk olahan salak khas Jatirejo dapat dipasarkan ke wilayah yang lebih luas lagi. Selain itu, juga telah dilakukan uji kualitas air untuk produk minuman sari salak, sehingga dapat menjamin kualitas produk agar konsumen tidak khawatir tentang keamanan produk tersebut. Dalam aspek pemasaran, kelompok mitra saat ini memasarkan produk olahan salak desa Jatirejo masih terbatas pada lingkungan dekat, saudara, serta mengikuti pameran UMKM yang diselenggarakan di sekitar wilayah Kabupaten Jombang. Hal ini dikarenakan, kelompok mitra masih dalam proses pengajuan ijin PIRT ke Dinas Kesehatan Kabupaten Jombang. Apabila kelompok mitra telah memperoleh ijin PIRT, maka pemasaran dapat dilakukan dengan lebih optimal. Adapun dalam hal permodalan, kelompok mitra difasilitasi oleh Kepala Desa Jatirejo, melalui kerjasama dengan dana Desa yang dikelola oleh Badan Usaha Milik Desa (BUMDes). Dengan adanya kerjasama tersebut, maka masalah permodalan kelompok mitra dapat diselesaikan, sehingga dapat melakukan kegiatan usaha dengan lebih optimal.

Dari hasil produksi yang telah dilakukan selama bulan Mei hingga Juli Tahun 2018, kelompok mitra telah melakukan penjualan minuman sari salak sebanyak 16.000 cup ukuran $250 \mathrm{ml}$, dan sebanyak $150 \mathrm{~kg}$ jenang salak, di mana konsumen yang membeli produk olahan salak tersebut berasal dari daerah sekitar Jawa Timur, Jawa Barat, Jakarta, Bali dan Sulawesi Utara. Dari hasil penjualan yang dilakukan, dapat diambil kesimpulan sementara bahwa, produk olahan salak desa Jatirejo memiliki potensi pasar yang bagus, meskipun sebagian besar konsumennya masih terbatas di wilayah Jawa Timur.
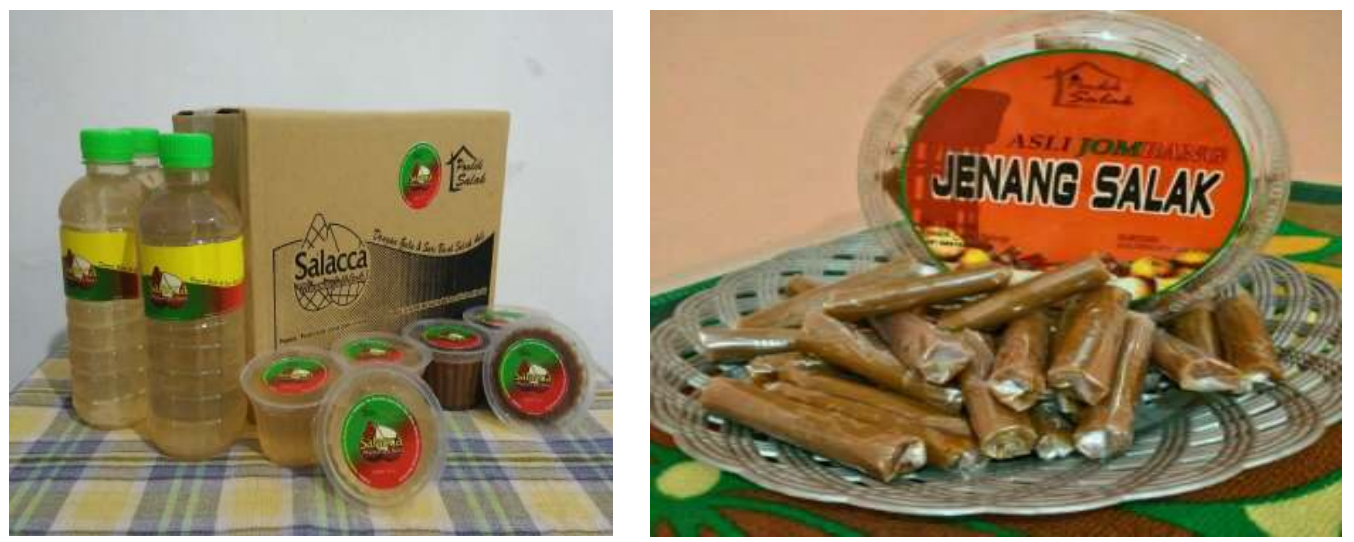

Gambar 3. Produk olahan salak yang siap dipasarkan

Sumber : Dokumentasi, 2018 


\section{E. PENUTUP}

Program Kerjasama Mitra (PKM) yang dilaksanakan adalah sebuah kegiatan pendampingan pada masyarakat pelaku usaha yang berada di desa Jatirejo Kecamatan Diwek Kabupaten Jombang, yang memiliki potensi usaha yang dapat berkembang pesat. Pada prinsipnya mitra sangat berkomitemen untuk mengembangkan produk olahan salak Jatirejo, serta memiliki semangat untuk memajukan usahanya serta mengembangkannya. Adapun Tim pendamping dalam mendampingi mitra, diperlukan upaya dan waktu untuk membina kelompok mitra agar memiliki produk yang berdaya saing di pasaran. Agar para pelaku usaha dapat berdaya saing, diharapkan pemerintah Desa Jatirejo terus mendorong kelompok mitra, sehingga dapat tumbuh menjadi sektor ekonomi yang dapat dibanggakan serta dapat meningkatkan citra Desa Jatirejo.

\section{DAFTAR PUSTAKA}

https://id.wikipedia.org/wiki/Salak_pondoh

Prawoto, N. (2012). Model Pengembangan Dan Pemberdayaan Masyarakat Berbasis Kemandirian Untuk Mewujudkan Ketahanan Ekonomi Dan Ketahanan Pangan (Strategi Pemberdayaan Ekonomi Pada Masyarakat Dieng Di Propinsi Jawa Tengah). Jurnal Organisasi dan Manajemen, 8(2), 135-154.

Rosfadhila, M., Toyamah, N., Sulaksono, B., Devina, S., Sodo, R. J., \& Syukri, M. (2011). Kajian Cepat Pelaksanaan Program Bantuan Langsung Tunai (BLT) 2008 dan Evaluasi Penerima Program BLT 2005 di Indonesia. SMERU Research Institute, 1-107.

Sumantra, I. K., Yuesti, A., \& Sudiana, A. K. (2015). Pengembangan model agrowisata salak berbasis masyarakat di Desa Sibetan. Jurnal Bakti Saraswati (JBS), 4(2).

Tempo.co. (2017, Januari 28). tempo.co. Retrieved from bisnis.tempo.co: https://bisnis.tempo.co/read/840600/kemendes-prioritaskan-ini-untuk-kemajuandesa-2017/full\&Paging=Otomatis

Zulfikar, W. (2017). Dampak Sosial, Ekonomi Dan Politis Dalam Pembangunan Bandara Udara Kertajati Di Kabupaten Majalengka. Jurnal Caraka Prabu, 1(01), $58-77$. 